\title{
Effects of Dietary Supplementation of a New Probiotic CS61 Culture on Performance in Broiler Chickens
}

\author{
Sung-Hwan Kim', In-Chul Lee', Hyung-Seon Baek', Seong-Soo Kang', Hyoung-Chin Kim², \\ Jin-Cheol Yoo ${ }^{3}$ and Jong-Choon $\mathrm{Kim}^{1}{ }^{*}$ \\ ${ }^{1}$ College of Veterinary Medicine, Chonnam National University, Gwangiu 500-757, Korea \\ ${ }^{2}$ Biomedical Mouse Resource Center, Korea Research Institute of Bioscience and Biotechnology, Chungbuk 363-883, Korea \\ ${ }^{3}$ College of Pharmacy, Chosun University, Gwangiu 501-759, Korea
}

Received November 1, 2011 /Revised February 3, 2012 / Accepted March 2, 2012

\begin{abstract}
Bacterial resistance to antibiotics and residues of antibiotics in poultry products have encouraged the use of probiotics, prebiotic substrates, and synbiotic combinations of prebiotics and probiotics as alternative approaches to the use of antibiotics in poultry. The present study was carried out to evaluate the effect of a new probiotic CS61 culture on growth performance, feed conversion efficiency, and safety in broiler chickens, and to evaluate its value as an alternative for antibiotics used as a feed additive. Two dosages of CS61 culture $(0.1 \%$ and $1 \%)$ were fed to chickens for 28 days. The results showed that terminal body weight and daily weight gain in the treatment groups increased in a dose-dependent manner when compared with the control group. Dietary supplementation with CS61 culture also improved feed conversion rate compared to the control group. There were no treatment-related toxic effects in terms of clinical findings, mortality, necropsy findings, hematology, or serum biochemistry parameters in any group tested. The nitric oxide assay showed that CS61 peptide has a dose-dependent inhibitory effect on lipopolysaccharide-induced nitric oxide production in RAW 264.7 cells. The results of this experiment indicated that dietary supplementation of CS61 culture may improve growth performance and feed conversion efficiency in chickens through its anti-inflammatory effect.
\end{abstract}

Key words : Broiler chickens, feed additive, probiotics, performance, safety

\section{서 론}

경제발전과 소득수준의 향상에 따라 안전하고 건강지향적 인 먹거리에 대한 요구가 크게 증가하고 있으나 식품매개질환 의 발생과 이로 인한 사회경제적 비용은 점차 증가하고 있는 추세이다[16]. 미국 질병관리예방본부(Centers for Disease Control and Prevention)의 자료에 의하면, 미국에서는 연간 약 7,600만 건의 식품매개질환이 발생하여 325,000 여 명이 입 원하고 5,200 여명이 사망하여 매년 약 1,520 억 달러의 경제적 손실을 초래한다고 한다[1]. 이러한 결과는 안전한 먹거리의 확보가 얼마나 중요한가를 단적으로 보여주는 좋은 예이며, 축산업에서도 안전한 축산물의 생산은 매우 중요한 이슈로 부각되고 있다. 대규모의 집약적 사육형태를 특징으로 하는 현대축산업에서는 가축의 질병을 예방하고 생산성을 높이기 위해 항생제를 사료첨가제로 많이 사용해 왔으나 항생제 사용 량의 증가로 내성균의 발생과 축산물의 항생제 잔류 등 많은 문제를 야기하게 되었다. 따라서 최근에는 이러한 문제를 해 결하기 위해 항생제의 사용을 점차 엄격하게 규제하게 되었

*Corresponding author

Tel : +82-62-530-2827, Fax : +82-62-530-2809

E-mail : toxkim@jnu.ac.kr
고, 가축의 질병예방과 사료효율 개선 및 성장촉진 기능을 가 지는 항생제 대체물질에 대한 연구가 광범위하게 이루어지고 있다[6].

최근 들어 항생제 대체물질로서 동물에게 유익한 미생물인 생균제(probiotics)에 대한 연구가 폭 넓게 수행되고 있다[3]. 생균제란 장내 미생물 균형을 개선시켜 줌으로써 숙주동물에 게 유익한 효과를 주는 균주형태의 생균제재를 말하며 $[2,4$, 13], 유산균, 효모, 고초균, 광합성균, 방선균 등이 축산분야에 서 주로 이용되고 있다[5,9]. 이러한 생균제가 항생제 대체물질 로서 각광받는 이유는 장내 정상세균총 형성에 도움을 주면서 도 병원성 미생물의 항생제 내성 발생과는 관련이 없기 때문 이다. 또한 항생제의 첨가로 인한 잔류문제를 유발하지 않고 장내 미생물의 균형유지와 대장균의 감소를 통한 지사작용 및 성장촉진 효과가 있다[12,18].

본 연구팀에서는 식품유래 미생물인 Bacillus subtilis 균주들 을 분리하였으며, 이들 중에서 상대적으로 항균활성이 우수하 면서도 독성이 낮은 생리활성물질을 생산하는 Bacillus subtilis CS61 균주를 선발하여 동물급여용 생균제 CS61 배양액을 개 발하였다. 본 연구는 CS61 배양액의 효능과 안전성을 평가하 고 항생제를 대체할 사료첨가제로서의 개발가능성을 알아보 기 위해 육계를 이용하여 성장률과 사료효율에 미치는 영향을 
평가하였다.

\section{재료 및 방법}

\section{공시동물 및 사양관리}

본 시험에 공시된 시험동물은 농촌진흥청에서 재래토종닭 으로 복원한 맛닭 초생추 99 마리(1일령, 평균체중 $38 \mathrm{~g}$ )를 우슬 재 농장(전북 부안)으로부터 구입하여 완전 무작위로 3 개 군에 배치하였다. 사양관리는 이전에 시험한 육계사양시험[8]과 같 이 온도 $21-32^{\circ} \mathrm{C}$, 습도 $60-70 \%$, 명암 12 시간 주기(조명: 08:00-20:00) 및 환기가 잘 되는 평사계사에서 육계의 사양방법 에 준하여 3 개 시험군을 동일하게 하였으며, 사료(육계전기, 대한사료)와 물은 자유급식 시켰다. 본 연구의 동물실험계획 서는 전남대학교의 동물실험윤리위원회의 승인을 받았으며, 모든 실험은 전남대학교의 동물실험규정에 따라 수행되었다.

\section{CS61 배양액의 준비}

Bacillus subtilis CS61 균주를 MRS 고체 배지(증류수 1 1에 universal peptone $10 \mathrm{~g}$, meat extract $5 \mathrm{~g}$, yeast extract $5 \mathrm{~g}$, $\mathrm{D}(+)$-glucose $20 \mathrm{~g}$, dipotassium hydrogen phosphate $2 \mathrm{~g}$, diammonium hydrogen citrate $2 \mathrm{~g}$, sodium acetate $5 \mathrm{~g}$, magnesium sulfate $0.1 \mathrm{~g}$ 및 manganous sulfate $0.05 \mathrm{~g}, \mathrm{pH}$ 6.5)에서 $37^{\circ} \mathrm{C}$ 조건으로 배양하였다. 24 시간 배양 후 한 개의 균주 집락 을 취하여 Maltose $1 \%$, Yeast extract 1\%를 함유한 $50 \mathrm{ml}$ 액체 배지에서 배양 하였다. 약 24 시간 후 배양한 액체배지는 전배 양액과 같은 조성의 배지 $250 \mathrm{ml}$ 가 들어있는 21 플라스크에 배지 부피의 $2 \%(\mathrm{v} / \mathrm{v})$ 수준으로 접종하고, $37^{\circ} \mathrm{C}$ 에서 $180 \mathrm{rpm}$ 으로 2-3일간 배양한 배양액을 실험에 사용하였다.

\section{시험군의 구성 및 시험물질 급여}

시험군은 대조군과 CS61 배양액 $0.1 \%$ 및 $1 \%$ 의 3 개 군으로 구성하였으며, 각 군당 시험동물은 33 수로 하였다. 시험사료 는 육계의 성장 시기별로 적절한 종류를 선택하여 대조군에는 기본사료를 급여하였으며, 시험군에는 기본사료에 무게 대비 $0.1 \%$ 와 $1 \%$ 의 농도로 CS61 배양액을 사료에 첨가한 후 배합기 를 이용하여 균질하게 혼합한 후 28 일간 자유급여 하였다.

\section{일반증상 및 사망률}

시험기간 중 매일 1 회 이상 공시동물의 일반증상과 사망동 물을 관찰하여 CS61 배양액의 질병예방기능을 평가하였다.

\section{체중 및 사료섭취량 측정}

체중은 각 시험군의 전 동물을 대상으로 시험개시일과 2주 및 4 주째에 개체별로 측정하여 성장촉진기능을 평가하였다. 시험기간 중 총 급여량에서 잔량을 제하여 마리당 사료섭취량 을 측정하였으며, 마리당 사료섭취량과 시험기간 중의 증체량
을 이용하여 사료요구율과 사료효율개선기능을 평가하였다.

\section{부검 및 병리소견 관찰}

시험물질 투여개시 후 29 일째에 $\mathrm{CO}_{2}$ 로 마취하여 방혈치사 시켰다. 안락사시킨 동물을 부검하여 주요 장기의 육안적 병 리소견을 관찰하였고, 혈액검사를 수행하여 시험물질의 안전 성을 평가하였다.

\section{혈액 및 혈청생화학 검사}

CS61 배양액 첨가사료를 28일간 급여한 후 부검 전날 각 군당 10 마리를 무작위로 선발하여 하룻밤 동안 절식한 다음 익하정맥에서 채혈하여 헤파린 튜브에 혈액을 수집하였다. 혈 액 검사는 Hemavet blood analyzer (Drew Scientific Co. USA) 를 이용하여 적혈구(red blood cells)와 혈색소(hemoglobin), 적혈구용적(hematocrit), 백혈구(leukocyte), 호중구(neutrophil), 단핵구(monocyte), 호산구(eosinophil), 호염기구(basophil) 및 혈소판(platelet)을 측정하였다. 혈청은 채혈된 혈액을 혈청 분리관(Iatron Laboratoies, Inc., Japan)에 넣고 15분간 상온에 방치하였다가 2,800 rpm으로 10 분간 원심분리하여 얻었다. 혈 청생화학검사는 혈청생화학 자동분석장치(Dri-chem $4000 \mathrm{i}$, Fujifilm Co., Japan)를 이용하여 알부민(albumin), 알카리성 포스파타제(alkaline phosphatase), 혈중요소질소(blood urea nitrogen), 칼슘(calcium), 콜레스테롤(cholesterol), 크레아티 닌(creatinine), 혈당(glucose), 알라닌 아미노전이효소(alanine aminotransferase), 젖산탈수소효소(lactate dehydrogenase), 비에스테르화지방산(non-esterified fatty acid) 및 총단백질 (total protein) 농도를 측정하였다.

\section{일산화질소(nitric oxide) 생성억제 시험}

먼저 CS61 배양액에서 항균 펩타이드를 정제하기 위하여 Bacillus subtilis CS61 균주를 71 발효조를 이용하여 Maltose $1 \%$ Yeast extract $1 \%$ 의 배지조건으로 $37^{\circ} \mathrm{C} 1 \mathrm{vvm}, 70 \mathrm{rpm}$ 의 조건으로 2-3일간 배양 하였다. 배양액은 원심분리기를 사용 하여 균사체와 배양여액으로 분리하였다. 배양여액은 약 41 였 으며 $60 \%$ 황산암모늄을 사용하여 활성 단백질을 침전시켰다. 활성분획의 충분한 회수를 위해 $60 \%$ 황산암모늄를 처리 후 $4{ }^{\circ} \mathrm{C}$ 에서 12 시간 동안 교반하였으며, 원심분리 $(6,000 \mathrm{rpm}, 60$ 분)하여 상등액은 제거하였다. 침전물을 $10 \mathrm{mM} \mathrm{Tris-HCl}(\mathrm{pH}$ 8.0)로 녹여 아미콘을 사용하여 $1 \sim 10 \mathrm{kDa}$ 사이의 분획으로 농축하였고 농축한 분획을 Sepharose CL-6B 컬럼(1.5X100 $\mathrm{cm})$ 을 이용하여 활성분획을 용출시켰다. 이 활성 분획을 다시 Sephadex G50 $(1 \times 60 \mathrm{~cm})$ 컬럼을 이용하여 순수한 펩타이드 (분자량 약 $1 \mathrm{kDa}$ )를 얻었다. Raw 264.7 세포를 분주한 96 well plate에 lipopolysaccharide (LPS, $1 \mathrm{ug} / \mathrm{ml}$ )와 정제한 CS61 펩 타이드를 농도별 $(0.05-1 \mathrm{mg} / \mathrm{ml})$ 로 처리한 후 12 시간 배양하였 다. 세포배양액에서 생성된 일산화질소의 양을 측정하기 위해 
동량의 Griess 시약(Sigma Chemical Co., MO, USA)을 첨가하 여 반응시킨 후 $540 \mathrm{~nm}$ 에서 흡광도를 측정하였다.

\section{통계분석}

얻어진 시험결과에 대한 통계분석은 GraphPad InStat v. 3.0 (GraphPad Software, Inc., CA, USA)을 이용하여 일원배 치분산분석(one-way analysis of variance)을 실시하였고, 유 의차 검정은 Student's $t$-test를 이용하여 $5 \%$ 및 $1 \%$ 에서 검정 하였다.

\section{결 과}

육계의 질병발생과 예방기능을 평가하기 위해 시험기간 중 일반증상과 사망동물을 관찰한 결과, 모든 시험군에서 특이적 인 이상소견은 관찰되지 않았다.

CS61 배양액의 성장촉진기능을 평가하기 위해 시험기간 중 육계의 체중변화를 관찰한 결과(Table 1$), 1 \%$ 시험군의 28 일째 체중이 대조군에 비해 통계학적으로 유의성 있게 증가하였다. 시험물질 투여군의 증체량을 대조군과 비교하였을 때 $0.1 \%$ 시험군에서는 약 $3.0 \%$, 그리고 $1 \%$ 시험군에서는 약 $20.3 \%$ 증 가하였다.

사료섭취량에 미치는 영향을 조사한 결과, 시험기간 중 각 시험군의 일일 사료섭취량은 거의 유사하게 나타났다(Table 2). 시험기간 중의 증체량과 사료섭취량을 이용하여 사료효율 개선기능을 평가한 결과(Table 2), $0.1 \%$ 시험군의 사료효율은 1.98 로서 대조군의 2.04 에 비해 미약하게 향상되었으나 $1 \%$ 시 험군의 사료효율은 1.67 로서 대조군에 비해 현저하게 향상되 었다.
CS61 배양액의 28 일간 급여에 따른 안전성을 평가하기 위 해 29일째에 부검하여 부검소견과 혈액 및 혈청생화학치를 분석하였다. 부검 시 근육(가슴살)과 흥강 및 복강장기, 위벽점 막, 뇌 등의 주요 장기를 관찰한 결과, 시험물질의 투여에 기인 된 어떠한 변화도 관찰되지 않았다(Fig. 1), 혈액학적 검사 결 과(Table 3), $0.1 \%$ 시험군의 적혈구수는 대조군에 비해 통계학 적으로 유의성 있게 감소하였으며, $1 \%$ 시험군의 백혈구와 호 중구, 단핵구 및 호산구 수도 각각 유의성 있게 감소하였다. 혈청생화학치를 분석한 결과(Table 4$), 0.1 \%$ 시험군에서 알카 리성 포스파타제와 칼슘이 대조군에 비해 각각 유의성있게 증가한 반면, 알라닌 아미노전이효소는 유의성있게 감소하였 다. $1 \%$ 시험군에서는 혈당 수치가 대조군에 비해 유의성있게 증가한 반면, 콜레스테롤과 알라닌 아미노전이효소는 대조군 에 비해 각각 유의성있게 감소하였다.

CS61 배양액의 항염증효과를 세포수준에서 확인하기 위해 정제된 CS61 펩타이드를 이용하여 일산화질소 합성저해실험 을 수행한 결과(Fig. 2), LPS 처리에 의하여 세포가 활성화되면 서 일산화질소 생성량이 대조군에 비해 약 2 배 정도 증가하였 다. 반면, CS61 펩타이드를 전처리했을 때에는 LPS에 의하여 급격히 증가했던 일산화질소 생성량이 용량의존적으로 감소 하였으며, 특히 $0.1 \mathrm{mg} / \mathrm{ml}$ 이상의 농도에서는 현저하게 감소 하였다.

\section{고 찰}

국민 소득수준의 향상과 식생활의 변화로 육류소비량은 크 게 증가하고 있으며[15], 특히 국내의 닭고기 소비량은 지난 10 년간 연평균 $4.4 \%$ 씩 증가하여 2005년에는 소고기 소비량을

Table 1. Body weights of chickens fed CS61 culture-containing diet for 28 days

\begin{tabular}{cccc}
\hline & \multicolumn{3}{c}{ Group } \\
\cline { 2 - 4 } & Control & $0.1 \%$ & $3 \%$ \\
\hline No. of chickens examined & 33 & 33 & 32 \\
Body weight $(\mathrm{g})$ : Day 0 & $38.9 \pm 2.06^{\mathrm{a}}$ & $37.0 \pm 2.25$ & $38.2 \pm 2.19$ \\
Day 14 & $233.8 \pm 24.88$ & $238.4 \pm 36.05$ & $235.8 \pm 28.02$ \\
Day 28 & $519.4 \pm 42.89$ & $531.8 \pm 39.41$ & $616.1 \pm 76.70^{* *}$ \\
Weight gain & $480.5 \pm 42.78$ & $494.8 \pm 40.08$ & $577.9 \pm 77.17^{* *}$ \\
\hline
\end{tabular}

${ }^{\mathrm{a}}$ Values are presented as means \pm SD.

** Significant difference at $p<0.01$ level compared with the control group.

Table 2. Feed efficiency of chickens fed CS61 culture-containing diet for 28 days

\begin{tabular}{lccc}
\hline & & Group & \\
\cline { 2 - 3 } & Control & $0.1 \%$ & $1 \%$ \\
\hline No. of chickens examined & 33 & 33 & 32 \\
Initial body weight (g/chicken) & 38.89 & 37.03 & 38.19 \\
Final body weight (g/chicken) & 519.40 & 531.81 & 616.10 \\
Weight gain (g/chicken/day) & 17.16 & 17.67 & 20.64 \\
Feed intake (g/chicken/day) & 34.96 & 34.96 & 34.52 \\
Feed efficiency (feed intake/weight gain) & 2.04 & 1.98 & 1.67 \\
\hline
\end{tabular}



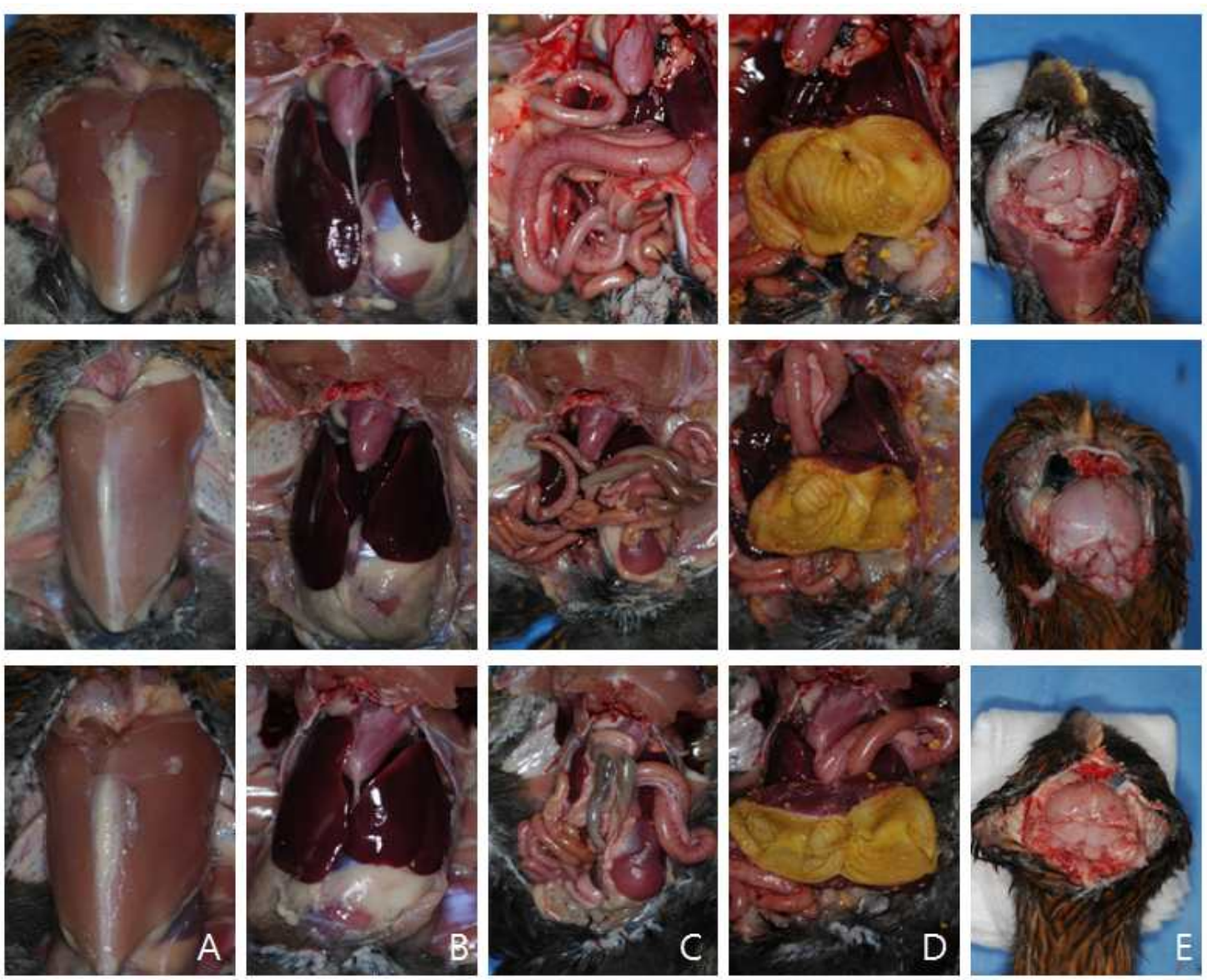

Fig. 1. Necropsy findings of chickens fed CS61 culture-containing diet for 28 days (A, muscles; B, heart and liver; C, intestine; D, gizzard; and E, brain). Upper panel, control group; middle panel, CS61 culture $0.1 \%$ group; and lower panel, CS61 culture $1 \%$ group.

Table 3. Hematological findings of chickens fed CS61 culture-containing diet for 28 days

\begin{tabular}{lccc}
\hline & \multicolumn{3}{c}{ Group } \\
\cline { 2 - 4 } & Control & $0.1 \%$ & $1 \%$ \\
\hline No. of chickens examined & 10 & 10 & 10 \\
RBC $\left(\times 10^{12} / \mathrm{l}\right)$ & $3.15 \pm 0.71^{\mathrm{a}}$ & $1.89 \pm 0.54^{* *}$ & $2.21 \pm 1.60$ \\
HB $(\mathrm{g} / \mathrm{dl})$ & $8.18 \pm 3.86$ & $6.38 \pm 2.79$ & $5.65 \pm 2.41$ \\
HCT $(\%)$ & $16.18 \pm 8.01$ & $12.62 \pm 3.39$ & $10.65 \pm 3.74$ \\
WBC $\left(\times 10^{9} / 1\right)$ & $41.66 \pm 9.16$ & $36.40 \pm 5.31$ & $28.61 \pm 4.34^{* *}$ \\
NEU $\left(\times 10^{9} / 1\right)$ & $26.31 \pm 5.88$ & $22.91 \pm 3.82$ & $17.94 \pm 4.34^{* *}$ \\
MON $\left(\times 10^{9} / 1\right)$ & $7.02 \pm 1.38$ & $6.14 \pm 1.66$ & $4.59 \pm 0.74^{* *}$ \\
EOS $\left(\times 10^{9} / 1\right)$ & $5.66 \pm 1.69$ & $4.96 \pm 0.19$ & $4.06 \pm 0.58^{* *}$ \\
BAS $\left(\times 10^{9} / 1\right)$ & $2.67 \pm 1.00$ & $2.40 \pm 0.29$ & $2.02 \pm 0.25$ \\
PLT $\left(\times 10^{9} / 1\right)$ & $849 \pm 1712.15$ & $1726 \pm 1929.40$ & $1084 \pm 973.68$ \\
\hline
\end{tabular}

Note. Values are presented as means \pm SD. RBC, red blood cells; HB, hemoglobin, HCT, hematocrit; WBC, white blood cells; NEU, neutrophil; MON, monocyte; EOS, eosinophil; BAS, basophil; and PLT, platelet.

${ }^{\text {a }}$ Values are presented as means \pm SD.

** Significant difference at $p<0.01$ level compared to the control group.

추월하였다. 이는 최근 건강에 대한 인식이 높아지면서 고단 백과 저칼로리, 저지방 및 저콜레스테롤 특성의 백색육인 닭 고기의 수요가 증가하였기 때문으로 판단된다. 육계산업에서
항생제는 질병예방과 사료효율개선 및 성장촉진을 위해 많이 사용되고 있으나 축산물 내 항생제 잔류와 내성균 출현 등으 로 큰 사회적 문제를 야기하고 있다. 따라서 국내에서는 현재 
Table 4. Serum biochemical findings of chickens fed CS61 culture-containing diet for 28 days

\begin{tabular}{lccc}
\hline & \multicolumn{3}{c}{ Group } \\
\cline { 2 - 4 } & Control & $0.1 \%$ & $1 \%$ \\
\hline No. of chickens examined & 10 & 10 & 10 \\
ALB (g/dl) & $1.67 \pm 0.06^{\mathrm{a}}$ & $1.62 \pm 0.09$ & $1.61 \pm 0.09$ \\
ALP (U/l) & $745.02 \pm 200.23$ & $1053.62 \pm 157.40^{* *}$ & $917.38 \pm 240.02$ \\
BUN (mg/dl) & $0.19 \pm 0.19$ & $0.15 \pm 0.08$ & $0.32 \pm 0.30$ \\
Ca (mg/dl) & $8.74 \pm 0.30$ & $9.47 \pm 0.47^{* *}$ & $8.62 \pm 0.33$ \\
CHO (mg/dl) & $155.20 \pm 11.01$ & $145.60 \pm 16.51$ & $136.16 \pm 16.31^{*}$ \\
CRTN (mg/dl) & $0.15 \pm 0.52$ & $0.28 \pm 0.09$ & $0.19 \pm 0.03$ \\
GLU (mg/dl) & $258.28 \pm 11.92$ & $262.68 \pm 7.15$ & $275.00 \pm 14.46^{* *}$ \\
ALT (U/l) & $18.84 \pm 1.93$ & $12.26 \pm 6.90^{*}$ & $11.32 \pm 3.83^{* *}$ \\
LDH (U/l) & $435.86 \pm 34.72$ & $445.34 \pm 50.20$ & $431.80 \pm 30.03$ \\
NEFA (mg/dl) & $0.43 \pm 0.31$ & $0.38 \pm 0.33$ & $0.35 \pm 0.26$ \\
TP (g/dl) & $4.97 \pm 0.36$ & $4.86 \pm 0.24$ & $4.94 \pm 0.11$ \\
\hline
\end{tabular}

Note. Values are presented as means \pm SD. ALB, albumin; ALP, alkaline phosphatase; BUN, blood urea nitrogen; Ca, calcium; CHO, cholesterol; CRTN, creatinine; GLU, glucose; ALT, alanine aminotransferase; LDH, lactate dehydrogenase; NEFA, non-esterified fatty acid; and TP, total protein.

${ }^{\text {a }}$ Values are presented as means \pm SD.

*, "** Significant difference at $p<0.05$ and $p<0.01$ levels compared to the control group.

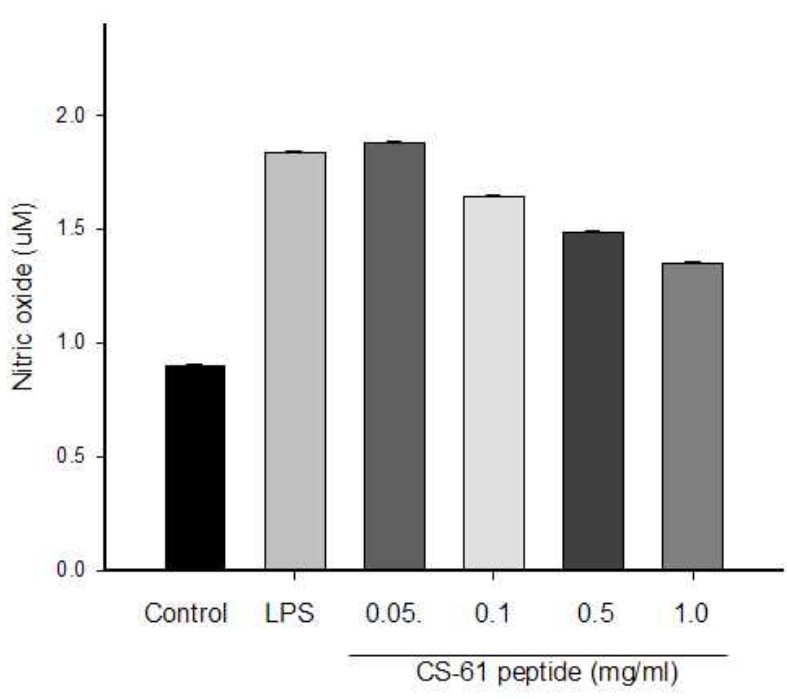

Fig. 2. Effects of CS61 peptide on lipopolysaccharide (LPS)induced nitric oxide production in RAW 264.7 cells.

배합사료 제조 시 첨가되는 7종의 항생물질(lincomycin, neomycin, penicillin, colistin, bacitracin, chlortetracycline 및 oxytetracycline)을 2009년부터 사용을 금지하였고[14], 2012년 부터는 항생제와 항균제의 사용을 전면 금지할 예정이다. 이 러한 배합사료용 항생물질의 감축정책과 안전한 축산물에 대 한 소비자의 요구로 인해 유기산제와 면역증진제, 식물추출 물, 생균제 등의 친환경적 항생제 대체물질에 대한 연구개발 은 크게 증가하고 있다. 그 중 생균제는 살아있는 미생물을 사용함으로써 영양효과와 건강효과 및 살균효과를 얻을 수 있어 큰 각광을 받고 있다[5,9,15].

이전 연구에 따르면, 생균제는 장내세균총의 정상화와 장에
서 잠재적 병원체 침입의 차단, 설사 예방 및 치료, 자극성 및 염증성 장 질환의 치료, 유당불내증(lactose intolerance)의 완화, 대장암의 예방, 면역기능의 조절, 헬리코박터 파일로리 (Helicobacter pylori)의 억제, 칼슘흡수의 향상, 콜레스테롤의 감소 등 다양한 효능이 있어서 식품으로서뿐만 아니라 수의축 산 분야에서도 폭 넓게 활용되고 있다 $[9,12,19]$. 본 연구에서는 식품유래 미생물 Bacillus subtilis CS61 균주를 이용하여 개발 한 CS61 배양액을 육계에게 28일간 사료에 혼합하여 급여한 결과, 본 생균제는 육계의 증체량을 향상시키고 사료효율을 개선하는 안전한 생균제로 확인되었다. 본 시험결과는 생균제 의 급여가 육계의 생산성을 향상시킨다는 이전 연구들의 결과 와도 잘 일치한다. Park 등[15]에 따르면, 복합생균제의 급여는 육계의 일당증체량과 사료요구율 및 도계율을 개선시킨다고 하였으며, Talebi 등[18]은 multi-strain의 생균제 PrimaLac이 육계의 체중을 증가시키고 사료요구율을 감소시킨다고 보고 하였다. 복합생균제가 육계의 생산성을 향상시킨다는 것은 상 기한 연구 외에도 국내외의 많은 연구에서도 잘 증명된 바 있다[7,9,10,21]. 상기한 문헌들과 본 시험의 연구결과는 생균 제의 급여가 육계의 증체율을 향상시키고 사료요구율을 감소 시켜 생산성을 향상시킨다는 것을 보여준다.

혈액 및 혈청생화학 분석시 $0.1 \%$ 시험군에서 관찰된 적혈 구수와 알라닌 아미노전이효소 활성의 감소, 그리고 알카리성 포스파타제와 칼슘의 증가는 용량상관성이 인정되지 않았거 나 관련되는 다른 항목의 변화와 일치하지 않아 시험물질의 투여와는 무관한 우발적 소견으로 판단된다. $1 \%$ 시험군에서 관찰된 혈당의 증가와 콜레스테롤 및 알라닌 아미노전이효소 수치의 감소 역시 간기능 이상 시에 관찰되는 소견들과 일치 하지 않아 시험물질의 투여에 의한 영향으로는 판단되지 않았 
다[20]. 본 시험에서는 최근에 재래토종닭으로 복원한 맛닭 초 생추를 사용하여 시험하였기 때문에 실험동물이나 계통이 잘 확립된 육계에 비해 유전적 동일성이 다소 떨어져 혈액 및 혈청학치의 변화가 크게 나타난 것으로 판단되며, 된다. 한편, $1 \%$ 시험군에서 관찰된 백혈구 수의 감소는 용량의존적으로 나타난 것으로 보아 시험물질의 투여에 의한 소견으로 사료되 었다. 그러나 다른 혈액 및 혈청학적 수치의 변화도 매우 컸고, 일반증상이나 체중변화 및 부검소견에서도 어떠한 이상도 인 정되지 않아 시험물질에 의한 독성영향으로는 판단되지 않았 다. 본 시험에서 관찰된 증체량과 혈액 및 혈청생화학치 변화 의 상관성을 명확히 규명하기 위해서는 보다 세부적인 후속연 구가 필요한 것으로 판단된다.

일산화질소는 세포 내 산화질소합성효소(nitric oxide synthase)에 의해 아미노산인 L-arginine이 분해되어 생성되며, 종양세포를 죽이거나 감염억제, 혈관이완 등의 중요한 역할을 수행한다[17]. 그러나 화학적으로 불안정하여 빠른 속도로 산 화되어 안정적이며 불활성 산화물인 아질산 $\left(\mathrm{NO}_{2}\right)^{-}$과 질산 $\left(\mathrm{NO}_{3}\right)$ 을 형성하게 되며, 과다하게 생성되면 쇼크에 의한 혈관 확장과 염증반응에 의한 조직손상, 돌연변이, 신경조직 손상 등의 유해작용을 나타내게 된다[11]. 본 시험에서는 CS61 배양 액의 항염증효과를 세포수준에서 확인하기 위해 정제된 CS61 펩타이드를 이용하여 일산화질소 합성저해 실험을 수행한 결 과(Fig. 1), LPS 단독처리군에서는 세포가 활성화되면서 일산 화질소의 생성량이 현저히 증가한 반면, CS61 펩타이드를 전 처리했을 때에는 LPS에 의해 증가된 일산화질소량이 용량의 존적으로 감소하였다. 특히, $0.1 \mathrm{mg} / \mathrm{kg}$ 이상 용량군에서의 일 산화질소 생성량은 LPS 단독군에 비해 통계학적으로 유의성 있게 감소하였다. 이러한 결과는 CS61 펩타이드가 일산화질 소 생성을 억제함으로써 여러 가지 원인에 의해 유발되는 염 증반응을 예방해줄 수 있으며, 또한 가축에서 발생하는 다양 한 염증질환의 예방에도 유용할 수 있음을 암시해 주고 있다.

결론적으로 생균제인 CS61 배양액의 사료첨가 급여는 육계 의 성장을 촉진하고 육질을 개선하는 효과가 있으며, 육계의 생산성을 증가시키는 안전한 사료첨가제로써 활용될 수 있을 것으로 생각된다.

\section{감사의 글}

본 논문은 2011년도 농촌진흥청 차세대 바이오그린사업 21 사업(과제번호: PJ008140)의 지원에 의해 이루어진 연구 이며, 이에 감사 드립니다. 또한 이 논문은 2010년도 정부 (교육과학기술부)의 재원으로 한국연구재단의 지원을 받아 수행되었으며(No. 2010-0029178), 이에 감사 드립니다. 또한 전남대학교 동물의학연구소의 일부 지원에 의해 수행되었 습니다.

\section{References}

1. CDC (Centers for Disease Control and Prevention). 2011. Foodborne Illness. Atlanta. Available at: http://www.cdc.gov/ ncidod/dbmd/diseaseinfo/foodborneinfections_t.htm (accessed 05 Oct 2011).

2. Chaucheyras-Durand, F. and H. Durand. 2010. Probiotics in animal nutrition and health. Benef. Microbes 1, 3-9.

3. Fuller, F. 1989. Probiotics in man and animals. J. Appl. Bacteriol. 66, 365-378.

4. Gaggìa, F., P. Mattarelli, and B. Biavati. 2010. Probiotics and prebiotics in animal feeding for safe food production. Int. J. Food Microbiol. 141, S15-28.

5. Higa, T. and J. F. Parr. 1994. Beneficial and effective microorganisms. In: International Nature Farming Research Center. Atami, Japan.

6. Kim, J. D., S. J. Auel, and K. S. Shim. 2010. Effects of feed additives as an alternative for antibiotics on growth performance and feed cost in growing-finishing pigs. Korean J. Org. Agric. 18, 233-244.

7. Kim, J. H., Y. M. Kim, S. C. Kim, M. H. Ha, Y. D. Ko, and C. H. Kim. 2001. Effect of dietary supplementation of probiotics $\left(E^{2}\right.$ conomix $\left.{ }^{\circledR}\right)$ on the performance of broiler chicks and noxious gas reduction in a broiler house. J. Anim Sci. Technol. 43, 349-360.

8. Kim, S. H., I. C. Lee, S. S. Kang, C. Moon, S. H. Kim, D. H. Shin, H. C. Kim, J. C. Yoo, and J. C. Kim. 2011. Effects of bamboo charcoal and bamboo leaf supplementation on performance and meat quality in chickens. J. Life Sci. 21, 805-810.

9. Kim, Y. R., B. K. Ahn, M. S. Kim, and C. W. Kang. 2000. Effects of dietary supplementation of probiotics $\left(\mathrm{MS}^{102 \otimes}\right)$ on performance, blood cholesterol level, size of small intestine and intestinal microflora in broiler chicks. J. Anim Sci. Technol. 42, 849-858.

10. Ko, Y. D., J. H. Sin, S. C. Kim, Y. M. Kim, K. D. Park, and J. H. Kim. 2003. Effects of dietary probiotic on performance, noxious gas emission and microflora population on the cecum in broiler. J. Anim Sci. Technol. 45, 559-568.

11. Korhonen, R., A. Lahti, H. Kankaanranta, and E. Moilanen. 2005. Nitric oxide production and signaling in inflammation. Curr. Drug Targets Inflamm Allergy 4, 471-479.

12. Lin, D. C. 2003. Probiotics as functional foods. Nutr. Clin. Pract. 18, 497-506.

13. Lutful Kabir, S. M. 2009. The role of probiotics in the poultry industry. Int. J. Mol. Sci. 10, 3531-546.

14. NVRQS (National Veterinary Research and Quarantine Service). 2008. Guidelines on animal medical supplies for formula feed production. Public Notice No. 2008-25, Anyang, Korea.

15. Park, S. H., J. S. Choi, D. S. Jung, J. H. Auh, and Y. I. Choi. 2010. Effects of complex probiotics and antibiotics on growth performance and meat quality in broilers. Korean $J$. Food Sci. Ani. Resour. 30, 504-511.

16. Shin, H., S. Lee, J. S. Kim, J. Kim, and K. H. Han. 2010. 
Socioeconomic costs of food-borne disease using the cost-of-illness model: applying the QALY method. J. Prevent. Med Pub. Health 43, 352-361.

17. Stamlar, J. S., D. J. Singel, and J. Loscalzo. 1992. Biochemistry of nitric oxide and its redox-activated forms. Science 258, 1898-1902.

18. Talebi, A., B. Amirzadeh, B. Mokhtari, and H. Gahri. 2008. Effects of a multi-strain probiotic (PrimaLac) on performance and antibody responses to Newcastle disease virus and infectious bursal disease virus vaccination in broiler chickens. Avian Pathol. 37, 509-512.

19. Yan, F. and D. B. Polk. 2010. Probiotics: progress toward novel therapies for intestinal diseases. Curr. Opin Gastroenterol. 26, 95-101.

20. Yang, Y. S., T. H. Ahn, J. C. Lee, C. Moon, S. H. Kim, W. Jun, S. C. Park, H. C. Kim, and J. C. Kim. 2008: Protective effects of Pycnogenol ${ }^{\circledR}$ on carbon tetrachloride-induced hepatotoxicity in Sprague-Dawley rats. Food Chem Toxicol. 46, 380-387.

21. Yu, D. J., J. C. Na, T. H. Kim, S. H. Kim, and S. J. Lee. 2004. Effect of supplementation of complex probiotics on performances, physico-chemical properties of meat and intestinal microflora in broiler. J. Anim Sci. Technol. 46, 593-602.

\section{초록 : 새로운 생균제 CS61 배양액의 사료 내 급여가 육계의 생산성에 미치는 영향}

김성환 $^{1} \cdot$ 이인철 ${ }^{1} \cdot$ 백형선 $^{1} \cdot$ 강성수 $^{1} \cdot$ 김형진 $^{2} \cdot$ 유진철 $^{3} \cdot$ 김종춘 $^{1}$ *

( ${ }^{1}$ 전남대학교 수의과대학, ${ }^{2}$ 한국생명공학연구원 의생명마우스센터, ${ }^{3}$ 조선대학교 약학대학)

가금류 제품에서 항생제의 잔류와 내성균의 출현으로 인해 항생제 대체물질에 대한 연구가 활발히 진행되고 있으며, 특히 생균제와 활성촉진제 또는 이들을 조합한 신바이오틱의 사용이 권장되고 있다. 본 연구는 새로운 생균제 CS61 배양액의 사료첨가 급여가 육계의 성장 및 사료효율에 미치는 영향과 안전성을 평가하여 항생제를 대체할 수 있는 사료첨가제로서의 개발가능성을 알아보기 위해 수행하였다. CS61 배양액은 0, 0.1 및 1\%의 용량 으로 28 일간 사료에 혼합하여 육계에게 급여하였다. 시험결과, 시험물질 처치군에서 부검 시의 체중과 일당증체 량이 대조군에 비해 용량의존적으로 증가하였다. CS61 배양액의 사료 내 첨가는 대조군 동물에 비해 사료효율도 개선하는 것으로 나타났다. 반면, 일반증상과 사망률, 부검소견, 혈액학치 및 혈청생화학치에서는 시험물질의 처 치와 관련된 독성소견이 관찰되지 않았다. RAW 264.7 세포를 이용한 일산화질소 시험에서 정제된 CS61 펩타이 드는 lipopolysaccharide에 유도된 일산화질소 생성을 용량의존적으로 억제하였다. 본 시험결과는 육계에 CS61 배양액의 사료첨가 급여는 항염증효과를 통해 성장과 사료효율을 개선할 수 있음을 보여주며, 사료첨가제로서 CS61 배양액의 유용성과 개발가능성을 시사해 주고 있다. 